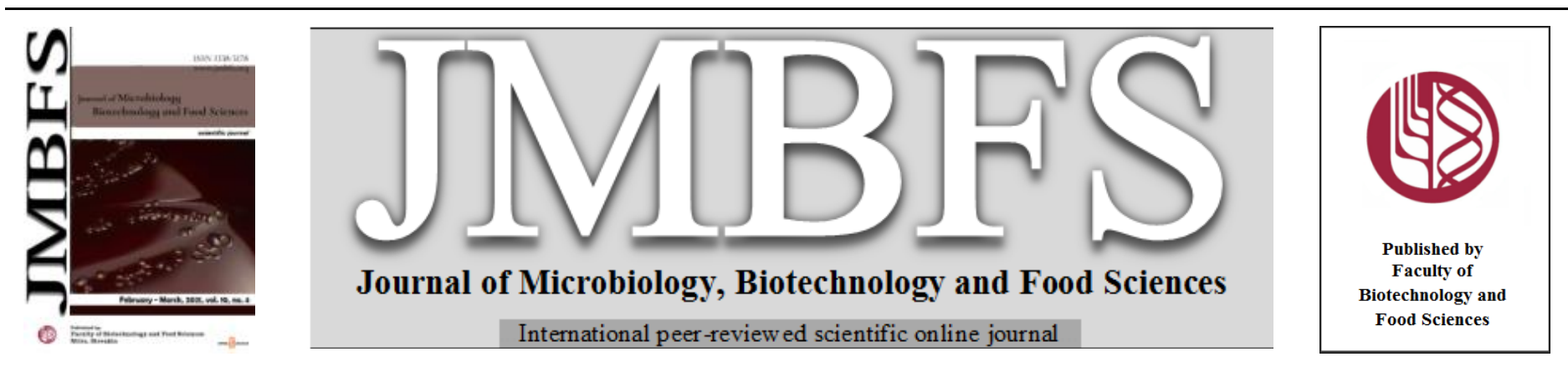

\title{
THE GENETIC VARIATION ASSESSMENT OF IN VITRO IRRADIATED TOMATO (Lycopersicon esculentum Mill) BY SCOT AND ISSR MARKERS
}

\author{
Ayman El-Fiki*1, Eman M. Fahmy ${ }^{2}$, Ahmed H. Abo Doma ${ }^{2}$, Osama Helmy ${ }^{1}$, Mohamed Adly ${ }^{1}$ and Gamal El-Metabteb ${ }^{1}$
}

Address(es): Prof. of Biotechnology Ayman El-Fiki,

${ }^{1}$ National Centre for Radiation Research and Technology, Atomic Energy Authority, Cairo, Egypt.

${ }^{2}$ Genetics Department, Faculty of Agriculture, Ain Shams University, Cairo, Egypt.

*Corresponding author: aymana.elfiki@eaea.org.eg

doi: 10.15414/jmbfs.2021.10.4.557-565

\section{ARTICLE INFO}

Received 4. 4. 2019

Revised 26. 9. 2019

Accepted 19. 10. 2019

Published 1. 2. 2021

Regular article OPEN $\partial_{\text {AcCESS }}$

\begin{abstract}
Tomato (Lycopersicon esculentum Mill.) are considered major and important globally vegetable crops and in Egypt in particular. Tissue culture techniques have encouraged the utilization of mutation methods in crop improvement. The mutation induction in vegetative crops through tissue culture may be the optimal method to improve these crops. Induced genetic variation in tomato plantlets by using gamma radiation and identified these changes through SCoT and ISSR markers. Egyptian tomato cultivar Idkawy explant was cultured onto MS medium supplemented with $0.2 \mathrm{mg}^{-1}$ BAP. The resulted plantlets were irradiated with $\gamma$ radiation doses $(50,100,150,200$ or $250 \mathrm{~Gy}$ ). The survival, growth rate, and mean of shoot length were decreased with increasing gamma radiation dose. The irradiated plantlets survival percentages were ranged from $78.75 \%$ to $(50 \mathrm{~Gy})$ and $18.75 \%$ to $(250 \mathrm{~Gy})$, whereas, the shoot length decreased by a rate of $2.71 \mathrm{~cm}$ for the dose $(50 \mathrm{~Gy})$ and $1.2 \mathrm{~cm}$ for dose $(250 \mathrm{~Gy})$. Genetic diversity was evaluated by SCoT and ISSR markers using ten primers for each. It was noticed that the polymorphism percentage mean of SCoT marker $(60.53 \%)$ is higher than the ISSR marker (39.6). The PIC values average for both markers SCoT and ISSR were 0.429 and 0.347 , as well, $M I$ values were 0.345 and 0.156 , respectively. On the other hand, the effective no. of alleles $(\mathrm{Ne})$, Nei's genetic diversity $(H)$ and Shannon's information index $(I)$ parameters, it was found that the dose $100 \mathrm{~Gy}$ caused the highest genetic variation compared with other doses using SCoT marker, however, in ISSR marker was dose of 150 Gy the highest dose for induced genetic variation. The obtained results demonstrate that SCoT marker was more accurate and efficient than ISSR marker for distinguishing and genetic variation analysis of irradiated tomato plantlets. The relationships within treatments were assessed through cluster analysis (UPGMA) based on SCoT and ISSR analysis.
\end{abstract}

\section{INTRODUCTION}

Tomato is certainly considered one among the most significant vegetable yields all inclusive and Egypt specifically, where it's miles second one most significant vegetable harvests after potatoes. The world cultivated area is about 3.7 million hectares producing about 100 tons of fresh fruit. In Egypt, tomatoes are cultivated on nearly $3 \%$ of the all out cultivated area, with a growing season from summer to winter, http://www.fao.org/faostat/en/\#data/QC. The in vitro techniques are perceived as valuable instruments in tomato improvement. The worth and significance of commercial tomato have been carried out many laboratory experiments in vitro to improve the crop through genetic manipulation (Evans, 1989). It is common in plant tissue culture to use many hormones and growth regulators to result in adventitious shoots. Cytokinins is the most widely recognized and used to obtain adventitious shoots from tomato explants such as zeatin, thidiazorun (TDZ), kinetin (KIN) and 6-benzylaminopurine (BAP), (ElBakry, A.A., 2002; Moghaieb et al. 1999; Mohamed et al. 2010; Kalyani et al. 2014). Genotype and physiological status, as well as cytokinins and auxins concentrations and ratios, are also important factors affecting on adventitious shoots formation and plant regeneration in tomato (Bhatia et al. 2004; Mamidala \& Nanna, 2011; Kumar et al. 2017). The decrease of genetic diversity in tomato via domestication and breeding has brought about the requirement for conservation, characterization, and usage of genetic resources (Terzopoulos \& Bebeli, 2008). Gamma radiation is ionizing radiation in which it reacts with atoms or molecules to provide free radical in cells. Gamma irradiation might actuate noteworthy morphological modifications in plant tissues in addition to a numerous of biochemical responses on the cellular level. Gamma radiation have given a high number of valuable mutants and is as yet indicating a raised potential for improving vegetative proliferated plants (Predieri 2001). Radicals may have a harmful effect on nucleic acid, carbohydrate and membrane lipids causing cell damage (Suzuki et al. 2012), or act on modifying the cell components and this impact may show up on the morphology, physiology, biochemistry, and anatomy depending on radiation doses. These impacts incorporate changes for the plant cell structure and metabolism, e. g. dilation of thylakoid membranes, modification in photosynthesis, balance of the antioxidative system and accumulation of phenolic compounds (Kim et al., 2004; Wi et al., 2005). The utilize of molecular markers not only depends on the appraisal of germplasm collections genetic variation but also on the distinction between the genotypes of populations. The SCoT marker technique depends on the single primer amplified region precept in which it makes use of a single primer as a forward and reverse primer, proven dominant markers just like the RAPD or ISSR technique. However, the usage of PCR amplification to SCoT primers objectives gene regions surrounding the ATG inception codon on each DNA strands. The SCoT markers are anticipated upon to be linked to functional genes and corresponding traits, as a result the amplicons may be converted to gene-targeted marker systems (Xiong et al., 2011). Generally, SCoT markers were reproducible but the factors determining reproducibility as primer length and annealing temperature are not the only factors (Collard \& Mackill, 2009). Inter simple sequence repeat (ISSR) marker is additionally relies upon PCR method. This technique relies upon on amplifying a segment of DNA this is at a distance that may be located among two identical microsatellite repeat regions oriented in contrary directions. Usually the ISSR technique use single primer with lengthy ranged from 16- $25 \mathrm{bp}$, the PCR reaction targeting multiple genomic loci to amplify distinctive amplicons. Microsatellite repeats primers have been used may be di-nucleotide, tri-nucleotide, tetra-nucleotide or penta-nucleotide and either unanchored (Gupta et al., 1994; Meyer et al., 1993; Wu et al., 1994; Ng \& Tan, 2015) or anchored at ' 3 or ' ' 5 end with one to four degenerate bases extended into the flanking sequences (Zietkiewicz et al., 1994). The aim of this study is to investigate the effect of some hormones and growth regulators on plant regeneration, determine the impact of gamma radiation doses on plantlets growth and survival, as well the mutagen of gamma radiation induced morphological and genetical variations, and evaluate the effectiveness of SCoT 
and ISSR markers for genetic variation analysis in tomato plantlets (Lycopersicon esculentum Mill.) Idkawy.

\section{MATERIAL AND METHODS}

\section{Seed Material}

Tomato Seeds, Idkawy cultivar were obtained from Agricultural Research Centre, Vegetable Research Institute, Ministry of Agriculture, Egypt.

Seeds were sterilized by dipping in Clorox $(30 \%)$ for ten minutes followed by three rinses in sterile distilled water. The seeds have been cultured on solid MS medium Murashige \& Skoog (1962) hormone free. The propagation process began after six to eight weeks when the length of the plantlets was $12 \mathrm{~cm}$. The culture was maintained through cutting into single nodes. The culture medium supplemented with different concentrations of hormones has been tested as, NAA, KIN, IAA, IBA or/ and BAP Table 1. A further 100 segments were cultured onto MS medium on each hormone. The $\mathrm{pH}$ of the culture medium was adjusted to 5.7 before autoclaving and the buds were thereafter incubated in the growth chamber at $25^{\circ} \mathrm{C} \pm 2$ under photoperiod $16 \mathrm{~h}$

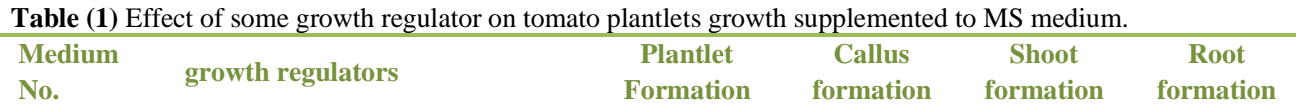

\begin{tabular}{llcccc}
\hline $\mathbf{1}$ & $8 \mathrm{mg}^{-1} \mathrm{NAA}+0.01 \mathrm{mg} / \mathrm{L} \mathrm{KIN}$ & + & + & + & - \\
$\mathbf{2}$ & $0.5 \mathrm{mg} / \mathrm{L} \mathrm{IAA}$ & ++ & - & + & + \\
$\mathbf{3}$ & $\mathrm{MS}$ & +++ & - & + & + \\
$\mathbf{4}$ & $5 \mathrm{mg} / \mathrm{L} \mathrm{BAP}$ & - & - & + & - \\
$\mathbf{5}$ & $0.1 \mathrm{mg} / \mathrm{L} \mathrm{IBA}$ & +++ & - & + & + \\
$\mathbf{6}$ & $0.2 \mathrm{mg} / \mathrm{L} \mathrm{BAP}$ & ++++ & - & + & + \\
\hline
\end{tabular}

$(+)=$ weak,$(++)=$ medium,$(++++)=$ High

\section{Gamma irradiation}

Irradiation was carried out with the ${ }^{137} \mathrm{Cs}$ source at the dose rate $1 \mathrm{~Gy} / 2 \mathrm{~min} 30$ sec, at National Centre for Radiation Research and Technology, Cairo, Egypt.

Tomato seeds soaked in water and exposed to distinct gamma irradiation doses $(50,100,150,200$ and $250 \mathrm{~Gy})$. An in addition 80 seeds had been irradiated with gamma rays at every dose. The irradiated seeds had been sterilized by dipping in Clorox $(30 \%)$ for ten mins accompanied by 3 rinses in sterile distilled water. The seeds had been cultured on solid MS medium Murashige \& Skoog (1962) hormone free. Micropropagation started out after 6- eight weeks whilst the plantlets had been approximately $10-12 \mathrm{~cm}$ high. The culture was maintained by cutting into single nodes and transferring them onto MS medium supplemented with $0.2 \mathrm{mg} / \mathrm{L}$ BAP. The $\mathrm{pH}$ of the culture medium was adjusted to 5.7 before autoclaving and the buds had been thereafter incubated in the growth chamber at $25^{\circ} \mathrm{C} \pm 2$ under photoperiod $16 \mathrm{~h}$

\section{Genomic DNA Extraction}

Total genomic DNA was isolated from about two grams of irradiated plantlets and grew on MS medium supplemented with $0.2 \mathrm{mg}^{-1}$ BAP according to the protocol described by Anderson et al. (1992) with a few modifications intended to improve the quality of DNA: two consecutive extractions with phenol: chloroform (1:1) were carried out by an additional wash of $97 \%$ alcohol (left at $20{ }^{\circ} \mathrm{C}$ for one hour) an $70 \%$ pre-cooled ethanol, respectively El-Fiki \& Adly (2019). The yield and quality of DNA had been assessed by gel electrophoreses.

\section{SCoT - PCR amplification}

Ten (SCoT) primers had been selected according to Collard \& Mackill (2009), (Table 2). Amplification reactions had been achieved in a total volume of $25 \mu 1$, which contained $250 \mu \mathrm{M}$ of every primer, $0.2 \mathrm{mM}$ of every deoxynucleotide, 1.5 $\mathrm{mM} \mathrm{MgCl}_{2}$, 1 unit Taq polymerase, and 50- $100 \mathrm{ng}$ of template DNA. All reaction volumes had been $25 \mu \mathrm{l}$ overlaid with a drop of mineral oil. The thermocycling program used was: one cycle at $94{ }^{\circ} \mathrm{C}$ for $3 \mathrm{~min}, 35$ cycles at 94 ${ }^{\circ} \mathrm{C}$ for $50 \mathrm{sec}, 1 \mathrm{~min}$ at $50{ }^{\circ} \mathrm{C}, 2 \mathrm{~min}$ at $72{ }^{\circ} \mathrm{C}$, and the final extension step of $7 \mathrm{~min}$ at $72{ }^{\circ} \mathrm{C}$. Electrophoresis was done to visualize the PCR amplified product. It was carried out on $1.0 \%$ agarose gel and amplified fragments had been visualized by staining with ethidium bromide (Ezzat et al. 2019).

\section{ISSR - PCR amplification}

Ten different ISSR primers which have been selected are eleven or 18 nucleotides based on di-, tri- or tetra-nucleotide SSR repeats with 2 nucleotides ' 3 selective anchor as follows; $(\mathrm{AG})_{8} \mathrm{YC},(\mathrm{AG})_{8} \mathrm{YT},(\mathrm{AG})_{8} \mathrm{YG},(\mathrm{AC})_{8} \mathrm{YG},(\mathrm{AC})_{8}$ $\mathrm{YC},(\mathrm{AC})_{8} \mathrm{YA},(\mathrm{GT})_{8} \mathrm{YG},(\mathrm{CTC})_{5} \mathrm{TT},(\mathrm{CAC})_{3} \mathrm{GC}$ and GAC(GATA) $)_{4}$ Table 2 Amplification reactions had been completed in a $25 \mu$ l volume, containing: 20 $\mathrm{mM}$ Tris- $\mathrm{HCl}$ (pH 8.4), 50mM KCl, $2.5 \mathrm{mM} \mathrm{MgCl} 2,200 \mu \mathrm{M}$ each of dNTPs, 1 $\mu \mathrm{M}$ primer, $30 \mathrm{ng}$ of genomic DNA $1.5 \mathrm{U}$ of Taq DNA polymerase. The reaction mixture was overlaid with two drops of mineral oil, incubated for $3 \mathrm{~min}$. at $95^{\circ} \mathrm{C}$ for initial denaturation, and then amplified for 45 cycles consisting of the $30 \mathrm{~s}$ at $94{ }^{\circ} \mathrm{C}, 30 \mathrm{~s}$ at $45^{\circ} \mathrm{C}$ and $60 \mathrm{~s}$ at $72{ }^{\circ} \mathrm{C}$ followed by $7 \mathrm{~min}$. incubation at $72{ }^{\circ} \mathrm{C}$. Amplification products were separated by gel electrophoresis on precast $0.8 \%$ agarose and visualized under UV illumination after staining with ethidium bromide and photographed (El-Fiki et al. 2017).

Data analysis

Fragment sizes of each SCoT and ISSR had been decided with PyElph 1.4 software (Pavel \& Vasile 2012) comparison with the DNA marker. Amplified products had been scored as present (1) or absent (0) to form a binary matrix. So as to quantify the informativeness of the markers to distinguish among genotypes, polymorphism information content (PIC) and marker index (MI) had been calculated. PIC was calculated consistent with to the formula of Anderson et al. (1992), as PIC $=1-\Sigma p_{i}^{2}$ where $p i$ is the frequency of the $i$ th allele of the locus in six gamma radiation treatments. MI was decided according to Varshney et al. (2007), because the fabricated from PIC and effective multiplex ratio. To characterize genetic variation, a few parameters, which includes the effective number of alleles $(\mathrm{Ne})$, Nei's gene diversity $(H)$ and

Table 2 Primers code and nucleotide sequences of the ten used SCoT and ISSR primers.

\begin{tabular}{|c|c|c|c|c|c|c|}
\hline \multicolumn{4}{|c|}{ SCoT } & \multicolumn{3}{|l|}{ ISSR } \\
\hline No. & Marker & Sequences $\left(5^{\prime}-3^{\prime}\right)$ & $\begin{array}{l}\% \\
\text { GC }\end{array}$ & Marker & Sequences $\left(5^{\prime}-3^{\prime}\right)$ & Repeat motif \\
\hline 1 & SCoT- 1 & 5'-CAACA_ATGGCTACCACCA-3' & 50 & ISSR1 & 5'-AGAGAGAGAGAGAGAGYC-3' & $(\mathrm{AG}) 8 \mathrm{YC}$ \\
\hline 2 & SCoT- 2 & 5'-CAACAATGGCTACCACCC-3' & 56 & ISSR2 & 5'-AGAGAGAGAGAGAGAGYG-3' & $(\mathrm{AG}) 8 \mathrm{YG}$ \\
\hline 3 & SCoT- 3 & 5'-CAACA_ATGGCTACCACCG-3' & 56 & ISSR4 & 5'-ACACACACACACACACYG-3' & (AC)8 YG \\
\hline 4 & SCoT- 4 & 5'-CAACAㅅTGGCTACCACCT-3' & 50 & ISSR5 & 5'-GTGTGTGTGTGTGTGTYG-3' & (GT)8 YG \\
\hline 5 & SCoT- 5 & 5'-CAACA_ATGGCTACCACGA-3' & 50 & ISSR7 & 5'-ACGATAGATAGATAGATA-3' & GAC(GATA)4 \\
\hline 6 & SCoT-12 & 5'-ACGACATGGCGACCAACG-3' & 61 & ISSR11 & 5'-ACACACACACACACACYA-3' & (AC)8 YA \\
\hline 7 & SCoT-13 & 5'-ACGACATGGCGACCATCG-3' & 61 & ISSR12 & 5'-ACACACACACACACACYC-3' & $(\mathrm{AC}) 8 \mathrm{YC}$ \\
\hline 8 & SCoT-16 & 5'-ACCATGGCTACCACCGAC-3' & 56 & ISSR13 & 5'-AGAGAGAGAGAGAGAGYT-3' & $(\mathrm{AG}) 8 \mathrm{YT}$ \\
\hline 9 & SCoT-20 & 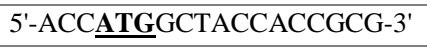 & 67 & ISSR14 & 5'-СТССТССТССТССТСТT-3' & (CTC)5 TT \\
\hline 10 & SCoT-33 & 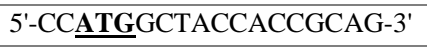 & 67 & ISSR24 & CAC CAC CAC GC & $(\mathrm{CAC}) 3 \mathrm{GC}$ \\
\hline
\end{tabular}


Shannon's information index $(I)$ had been calculated the usage of PopGen 1.3.1 software, (Yeh et al., 1990). Jaccard's similarity coefficient was calculated to assemble a similarity matrix and the UPGMA algorithm was used to carry out hierarchical cluster analysis and to assemble a dendrogram the usage MVSP, Ver 3. 1 Kovach, (1998).

\section{RESULTS AND DISCUSSION}

\section{Propagation of tomato in vitro}

For the selection of most suitable hormone for the growth of tomato plantlets, the explants had been cultured on MS medium supplemented with numerous hormones concentrations which include KIN, IAA, 6-BAP or/ and IBA. The impact of those hormones was the formation of callus, the difference in plantlets growth rates, the formation of plantlets without roots or intact plantlets proven with inside (Table 1). Based on those results, BAP at concentration $0.2 \mathrm{mg}^{-1}$ was the hormone that generated growth of tomato plantlets as proven in Table 1 Therefore, MS medium supplemented with $0.2 \mathrm{mg}^{-1}$ BAP was used for additional radiation experiments. For tomato regeneration, a huge assortment of plant growth regulators has been utilized at different concentrations. High shoot regeneration observed in different tomato cultivars when cotyledons, stems, leaves and hypocotyl cultured on MS medium supplemented with 5.0 $\mu \mathrm{M}$ BAP or 1.0 mg-1 zeatin (Pino et al., 2010; Godishala et al., 2012; Arkita et al., 2013) However, Bookout and Noble (1987) found that the supplemented IAA to MS medium decrease regeneration and enhance shoot induction by $20 \%$.

\section{Effect of gamma radiation on tomato survival plantlets}

Plantlets of tomatoes had been irradiated with numerous gamma radiation doses $(0,50,100,150,200$ or $250 \mathrm{~Gy})$. The survival of irradiated plantlets was reduced with increasing gamma radiation doses as illustrated in Fig 1. The number of plantlets survival percentages ranged from $78.75 \%$ ( $50 \mathrm{~Gy}$ ) to $18.75 \%$ (250 Gy). As well the mean of plantlets shoot length was decreased with increasing gamma radiation doses as shown in Table 3, where the shoot length decreased by a rate of $2.71 \mathrm{~cm}$ for the dose $50 \mathrm{~Gy}$ and $1.2 \mathrm{~cm}$ for dose $250 \mathrm{~Gy}$. Plant regeneration may be acquired directly (Dwivedi et al., 1990), or indirectly via callus (Jawahar et al., 1997). An extensive variety of plant growth regulators at different concentrations have been utilized alongside various explants for various cultivars of tomato in different examinations for induction of callus and plant regeneration. The specific action of growth regulator depended both on genotype and physiological condition of the donor plant. A similar tendency of phytohormone impact on organogenesis was likewise seen by (Dewi et al., 2004; Miceska, 2011). Gamma ray is ionizing radiation react with atoms or molecules to provide free radical in cells. Radicals may also have a damage impact or act on rearranging the cell components and this impact may also seem at the morphology, physiology, biochemistry, and anatomy relying on radiation doses. These impacts include modifications with inside the plant cellular structure and metabolism, e. g. dilation of thylakoid membranes, alteration in photosynthesis, modulation of the antioxidative system and accumulation of phenolic compounds (Kim et al., 2004; Wi et al., 2005). Chronic exposure has to a great extent been utilized however doesn't seem to have any favorable circumstances over intense irradiation (Sigurbjörnsson, 1977), which is progressively reasonable for induced mutagenesis in tissue cultures. Generally, gamma irradiation may be used to achieve varieties which are economically essential in agriculture, with excessive productiveness and quality (Jain, 2010; El-Fiki et al., 2018) Mutations are of paramount significance to be used in breeding programs and in vitro mutagenesis in order to increase the genetic diversity required for plant improvement programs. Many mutant varieties have been developed, which are resistant to biotic and abiotic stress and with excessive quality (Jain et al., 2013) Several tries of mutagenic treatment on cultured anthers were mentioned in higher plants (Sangwan \& Sangwan, 1986; MacDonald et al., 1988; Ling et al., 1991; El-Fiki et al., 2015). These results had been acquired according with the radiation affectability test is done by Hasegawa et al. (1995), El-Fiki et al. (2015, 2016) for tobacco, (El-Fiki et al., 2018) for potato, El-Fiki et al. (2005a b) for alfalfa, Norfadzrin et al. (2007) for tomato and okra and Orthosiphon stamineus Kiong et al. (2008).

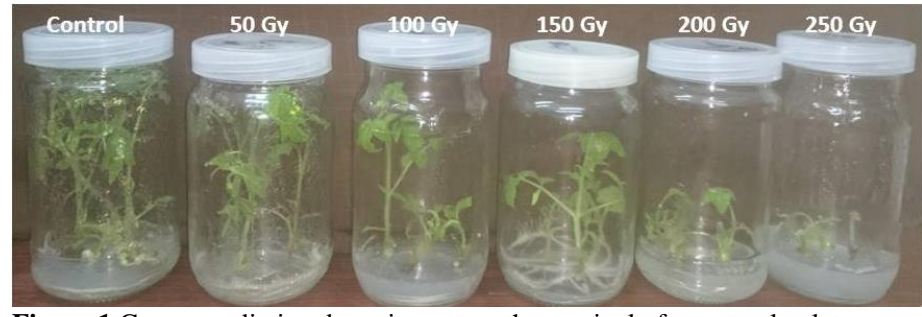

Figure 1 Gamma radiation doses impact on the survival of tomato plantlets

Table 3 Gamma irradiation doses impact on bud survival in tomato plantlet.

\begin{tabular}{lccc}
$\boldsymbol{\gamma}$-Radiation dose $/ \mathbf{G y}$ & $\begin{array}{c}\text { No. of growing } \\
\text { plantlets }\end{array}$ & $\begin{array}{c}\text { \% Bud } \\
\text { survival }\end{array}$ & $\begin{array}{c}\text { Mean of } \\
\text { shoot length } \\
\text { (cm) }\end{array}$ \\
\hline Control & 74 & 92.5 & 5.30 \\
\hline $\mathbf{5 0}$ & 63 & 78.75 & 2.71 \\
\hline $\mathbf{1 0 0}$ & 59 & 73.75 & 2.30 \\
\hline $\mathbf{1 5 0}$ & 40 & 50 & 2.00 \\
\hline $\mathbf{2 0 0}$ & 32 & 40 & 1.54 \\
\hline $\mathbf{2 5 0}$ & 15 & 18.75 & 1.20 \\
\hline
\end{tabular}

\section{Molecular Markers}

\section{The polymorphism of amplified products from irradiated tomato}

\section{SCot analysis}

Total genomic DNA from irradiated tomato plantlets (Lycopersicon esculentum Mill.) with diverse gamma irradiation doses 0, 50, 100, 150, 200 and $250 \mathrm{~Gy}$ have been used as templates for SCoT and ISSR genetic diversity analysis. The SCOT and ISSR analysis among irradiated plantlets are summarized in Table 4.

Table 4 Amplification consequences generated through SCoT and ISSR primers in irradiated tomato plantlets

Marker

\begin{tabular}{|c|c|c|c|c|c|c|c|c|c|c|c|c|c|}
\hline SCoT & & & & & & & ISSR & & & & & & \\
\hline & TAB & PBN & $\% \mathrm{~PB}$ & $\mathrm{BZ} / \mathrm{bp}$ & $M I$ & $P I C$ & & TAB & PBN & $\% \mathrm{~PB}$ & BZ/bp & $M I$ & $P I C$ \\
\hline SCoT- 1 & 13 & 9 & 69.23 & $137-686$ & 0.42 & 0.50 & ISSR-1 & 17 & 11 & 64.7 & $163-1553$ & 0.29 & 0.42 \\
\hline SCoT- 2 & 10 & 6 & 60.0 & $277-1166$ & 0.18 & 0.23 & ISSR-2 & 3 & 0 & 0.00 & $171-253$ & 0.14 & 0.42 \\
\hline SCoT- 3 & 14 & 7 & 50.0 & $258-1302$ & 0.42 & 0.50 & ISSR-4 & 9 & 4 & 44.4 & $169-470$ & 0.13 & 0.23 \\
\hline SCoT- 4 & 4 & 2 & 50.0 & $283-484$ & 0.21 & 0.42 & ISSR-5 & 13 & 6 & 46.1 & $142-1046$ & 0.22 & 0.42 \\
\hline SCoT- 5 & 18 & 12 & 66.67 & $161-1426$ & 0.41 & 0.50 & ISSR-7 & 10 & 3 & 30.0 & $175-743$ & 0.13 & 0.32 \\
\hline SCoT-12 & 15 & 13 & 86.67 & $172-747$ & 0.46 & 0.50 & ISSR-11 & 11 & 7 & 63.6 & 206-891 & 0.26 & 0.42 \\
\hline SCoT-13 & 12 & 9 & 75.0 & 159-1174 & 0.45 & 0.50 & ISSR-12 & 11 & 3 & 27.2 & $183-1052$ & 0.14 & 0.32 \\
\hline SCoT-16 & 5 & 1 & 20.0 & $133-684$ & 0.06 & 0.32 & ISSR-13 & 7 & 3 & 42.8 & $232-1038$ & 0.18 & 0.42 \\
\hline SCoT-20 & 8 & 3 & 37.5 & $285-953$ & 0.37 & 0.50 & ISSR-14 & 12 & 3 & 25.0 & $219-1682$ & 0.04 & 0.18 \\
\hline SCoT-33 & 15 & 7 & 46.67 & $255-1463$ & 0.47 & 0.32 & ISSR-24 & 8 & 0 & 0.00 & $169-836$ & 0.03 & 0.32 \\
\hline Total & 114 & 69 & & & 3.45 & 4.29 & Total & 101 & 40 & & & 1.56 & 3.47 \\
\hline Mean & 11.4 & 6.9 & 60.53 & & 0.345 & 0.429 & Mean & 10.1 & 4 & 39.6 & & 0.156 & 0.347 \\
\hline
\end{tabular}

Note: Total amplified band (TAB), Polymorphic band no. (PBN), \% polymorphic band (\%PB), Band size/bp (BZ/bp), Marker index (MI), Polymorphism information content $(P I C)$

Ten ScoT primers amplified (Fig. 2) a total 114 amplicons with a range of 4 to 18 bands per primer with an average 11.4 fragments per primer. The highest numbers of bands (13) were generated by primer SCoT- 5 , whereas the lowest number of bands (1) was generated by primer SCoT- 4 with an average 6.9 band per primer. The polymorphism varied from $20 \%$ to $86.67 \%$ with an average polymorphism of $60.53 \%$. The size of the amplified products ranged from $133 \mathrm{bp}$ (SCoT- 16) to $1463 \mathrm{bp}$ (SCoT- 33). The polymorphic Information content values (PIC) were varied from 0. 23 (SCoT- 2) to 0.50 (SCoT- 1, 3, 5, 12, 13and 20) 
with an average $0.429(P I C<0.5)$. Marker index $(M I)$ value, the highest value showed for SCot- 33 (0.47), while the lowest value observed to SCoT- $16(0.06)$ with an average 0.345 Table 4 .

\section{ISSR analysis}

A total of 101 bands were generated from ten ISSR primers (Fig. 3) and all of them are polymorphic bands by a range of 3 to 17 bands per primer with an average of 10.1 fragments per primer. The highest number of bands 11 observed by ISSR-1, while the lowest number was zero by ISSR- 2 and ISSR- 24 with an average of 4 bands per primer. The polymorphism percentage varied from $0 \%$ to $64.7 \%$, with the mean of polymorphism $39.6 \%$. The size of the amplified products ranged from $142 \mathrm{bp}$ (ISSR- 5) to $1682 \mathrm{bp}$ (ISSR- 14). The value of polymorphic information content (PIC) was varied from 0.18 (ISSR-14) to 0.42 (ISSR- 1, 2, 5, 11 and 13) with an average $0.347(P I C<0.5)$. Marker index value $(M I)$ was varied between 0.03 (ISSR- 24) and 0.29 (ISSR- 1) by an average 0.156 Table 4.

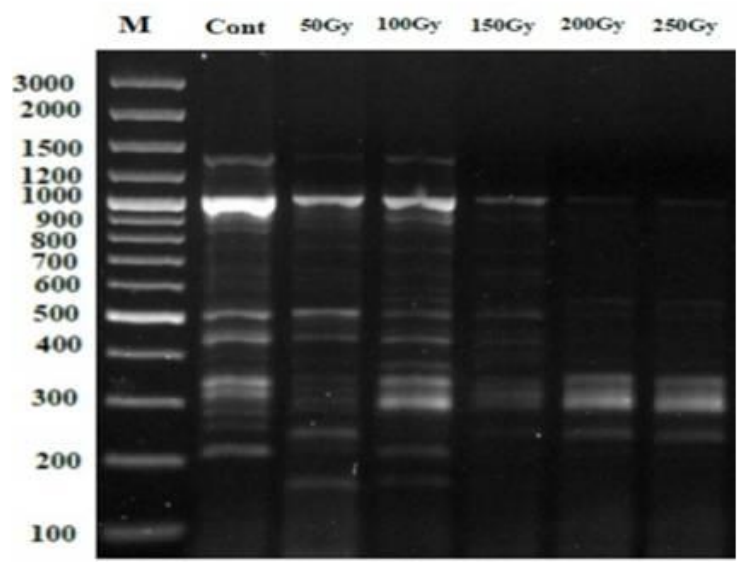

(E)

SCOT- 5
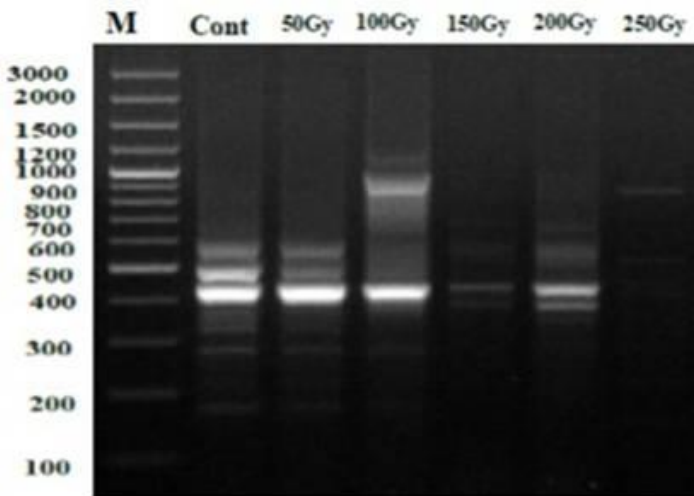

(G)

SCOT- 13

\section{Genetic diversity revealed by SCoT and ISSR markers}

The genetic diversity between irradiated tomato plantlets with different gamma irradiation doses $0,50,100,150,200$ or 250 Gy is summarize in Table 5. For the SCoT marker, the effective number of alleles $(\mathrm{Ne})$ value ranged from $1.3633 \pm 0.24$ (200 Gy) to $1.6478 \pm 0.28$ (100 Gy). Whereas, Nei's genetic diversity $(H)$ varied from $0.2499 \pm 0.10$ (200 Gy) to $0.3758 \pm 0.11$ (100 Gy). Also, the Shannon's information index $(I)$ ranged from $0.4097 \pm 0.12$ (200 Gy) to $0.5574 \pm 0.12(100 \mathrm{~Gy})$. It is noticeable in these results that the highest and least differences were found in irradiated plantlets with doses 100 and 200 Gy, respectively. On the other hand, the genetic diversity assessment by ISSR marker revealed an effective number of alleles $(\mathrm{Ne})$ ranging from 1.6516 $\pm 0.22(200 \mathrm{~Gy})$ to $1.7687 \pm 0.17$ ( $0 \mathrm{~Gy})$, as well as the highest and lowest value of Nei's genetic diversity $(H)$ was $0.4295 \pm 0.05(0 \mathrm{~Gy})$ and $0.3849 \pm 0.08(200 \mathrm{~Gy})$ respectively. Furthor, Shannon's information index $(I)$, was highest and lowest at nonirradiated plantlets ( 0 Gy) and (200 Gy) with $0.6198 \pm 0.05$ and $0.5704 \pm 0.08$ respectively. Of the results obtained, we note that the lowest genetic diversity values in both SCoT and ISSR analyzes was seen in plantlets irradiated at dose $200 \mathrm{~Gy}$, while the highest value was the non-irradiated plantlets in ISSR marker and plantlets irradiated with dose $100 \mathrm{~Gy}$.

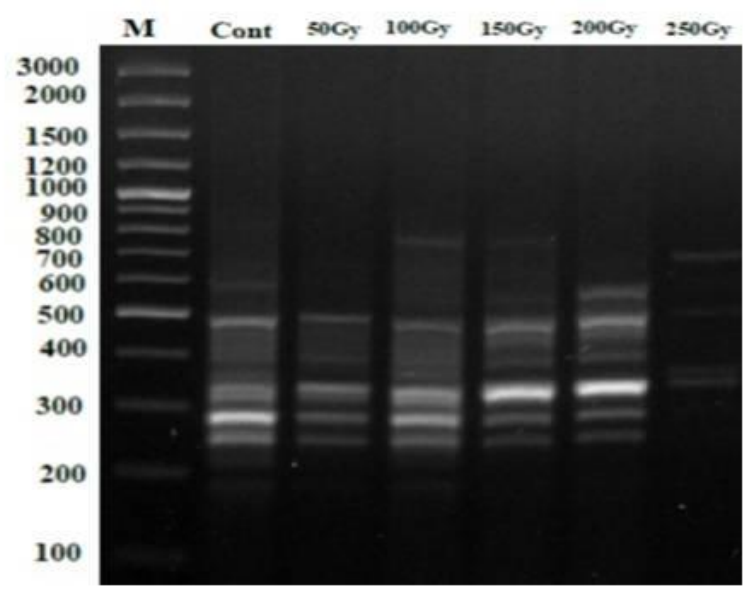

(F)

SCOT- 12

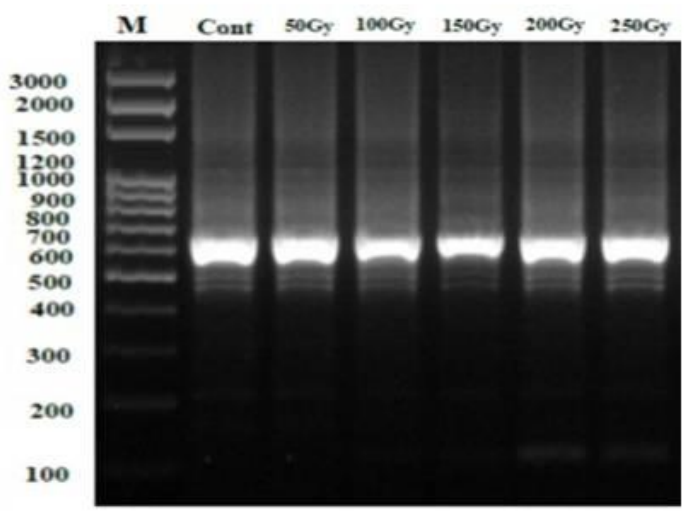

(H)

SCoT-16 


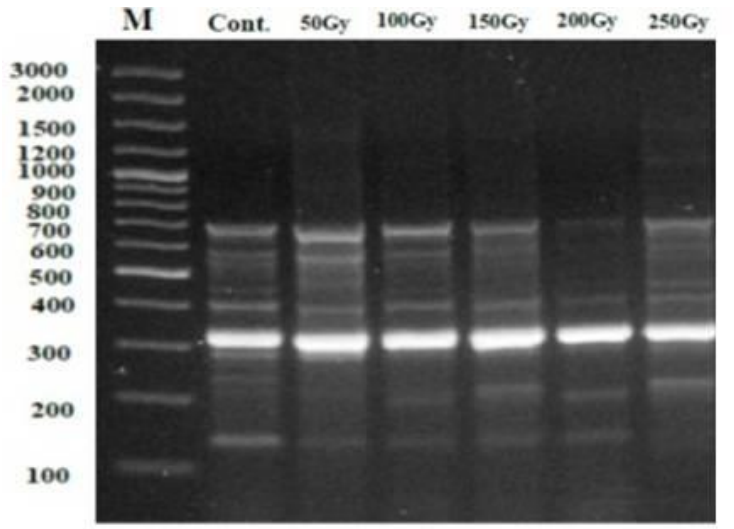

(A) SCOT- 1

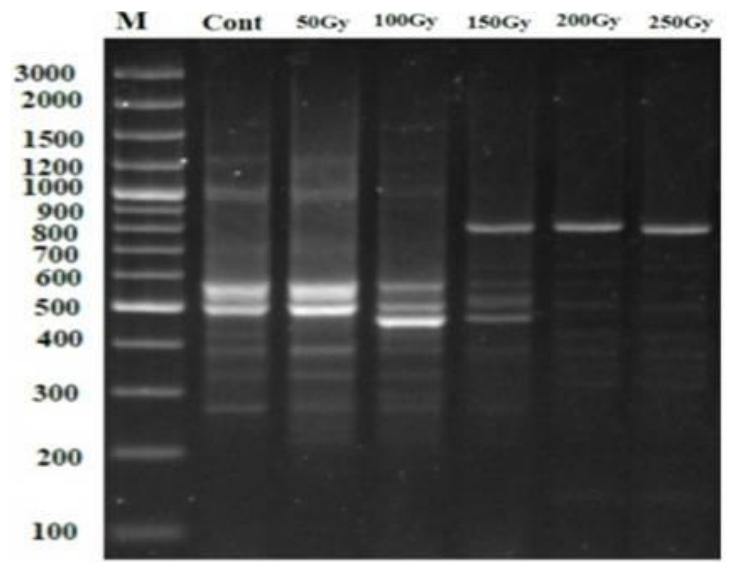

(C)

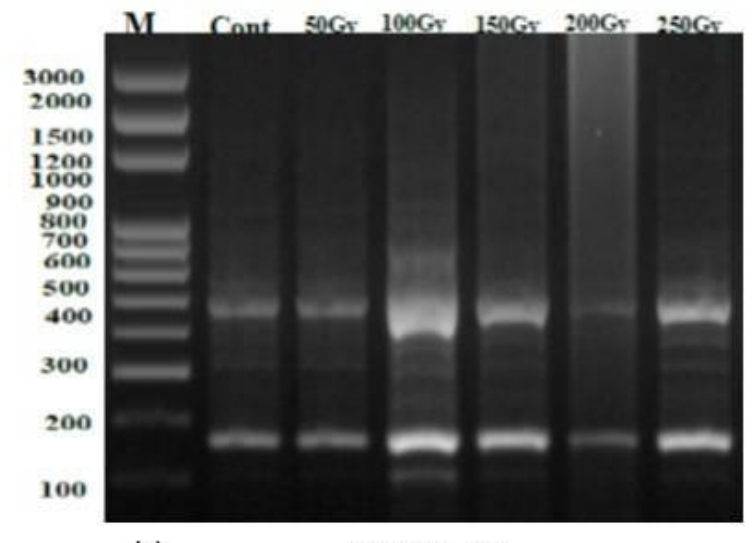

(I)
SCOT- 3

SCOT- 20

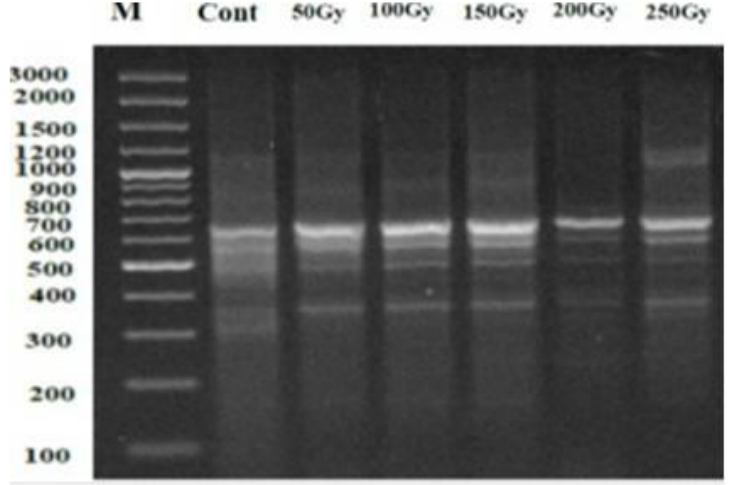

(B)

SCOT- 2

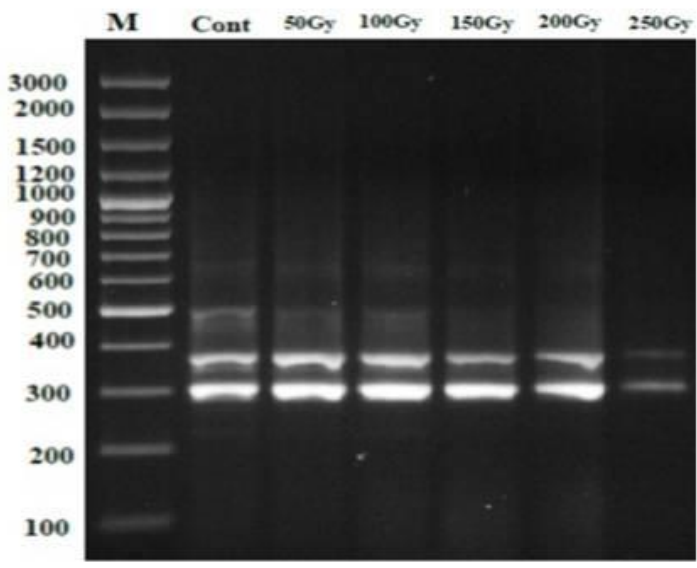

(D)

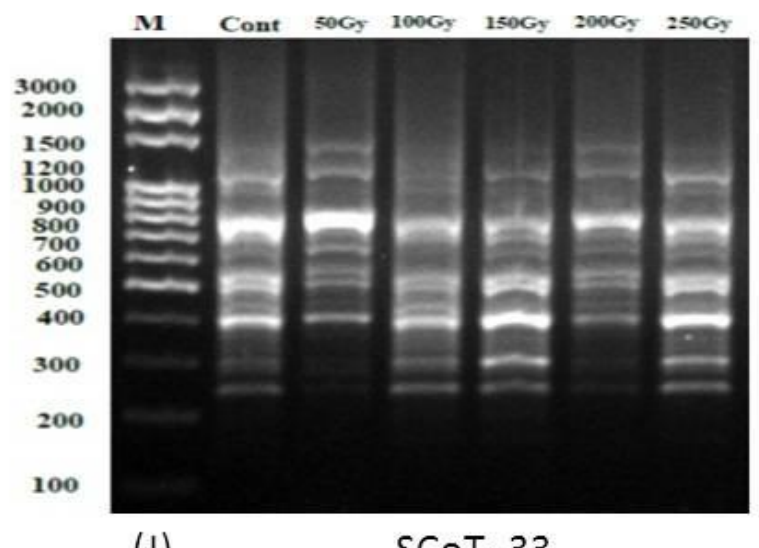

(J)

SCOT- 33

Figure 2 Representative of ten SCoT primers profile of irradiated tomato plantlets. Lane (1) Control (0 Gy); Lane (2) 50 Gy; Lane (3) 100 Gy; Lane (4) 150 Gy; Lane (5) 200 Gy; Lane (6) 250Gy. 


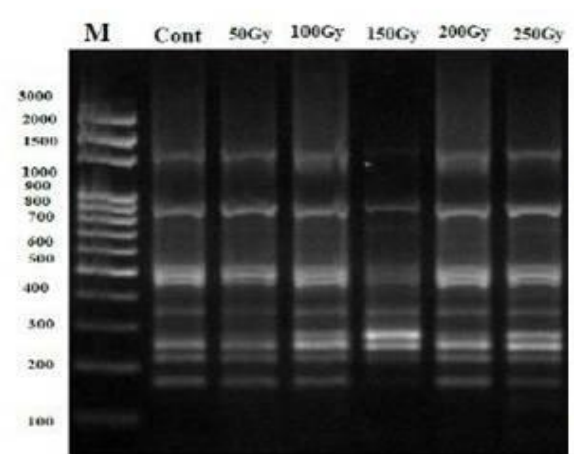

(A)

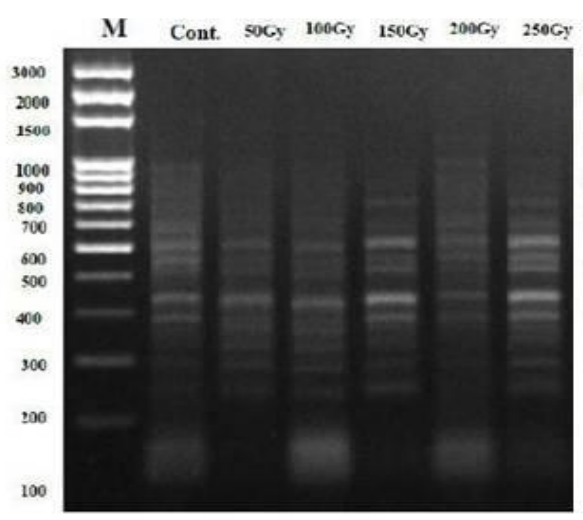

(D)

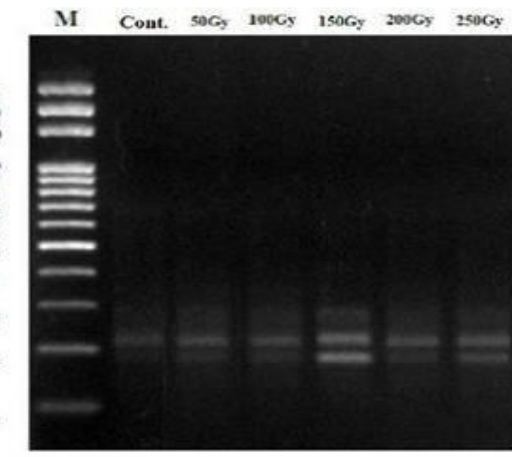

(B)

ISSR- 2

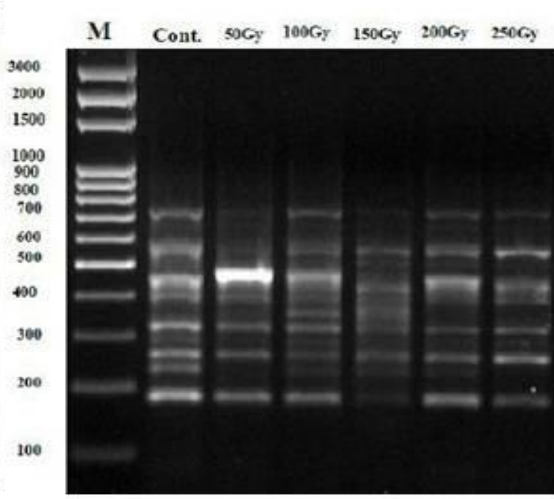

(E)

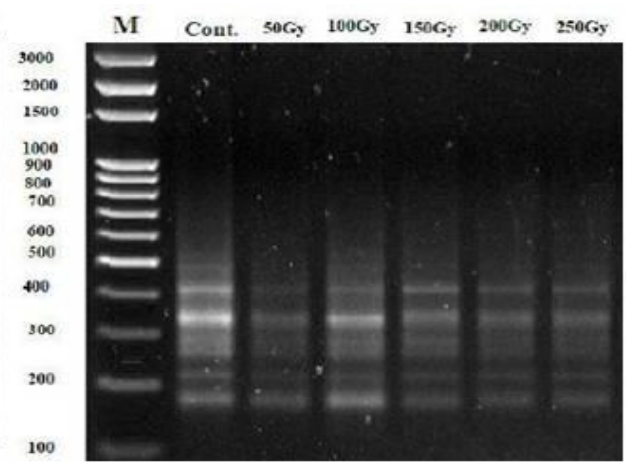

(C)

ISSR- 4

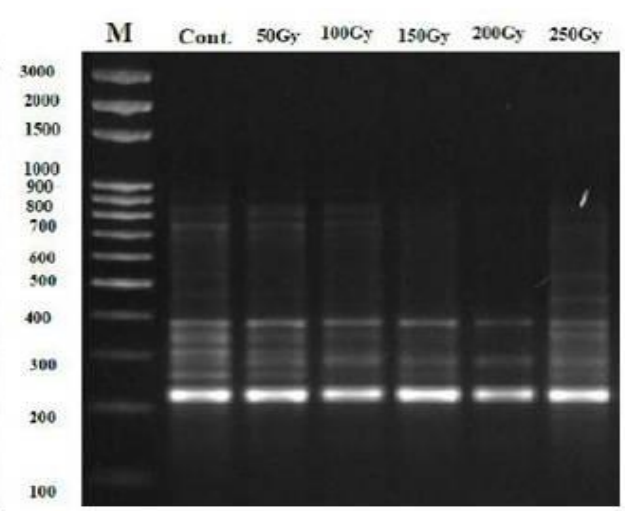

(F)

ISSR- 11

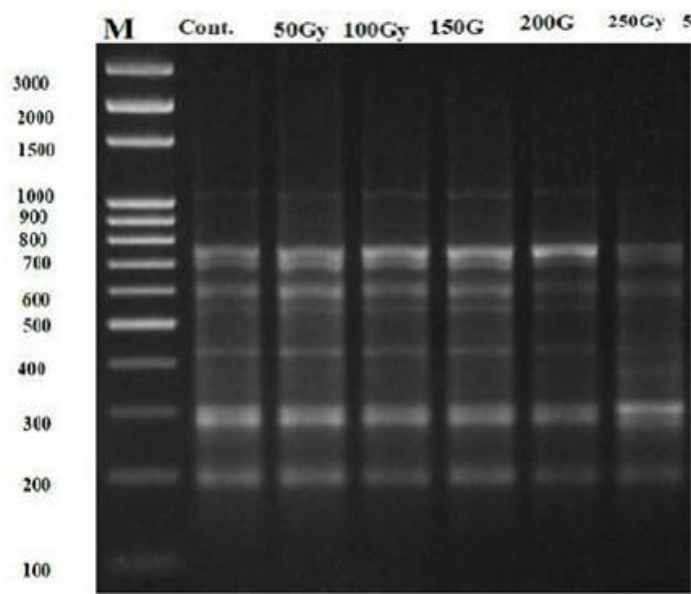

(G)

ISSR- 12

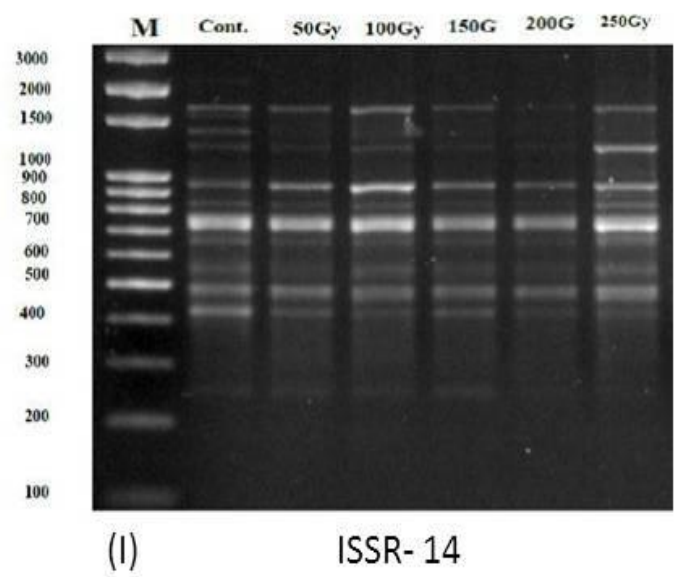

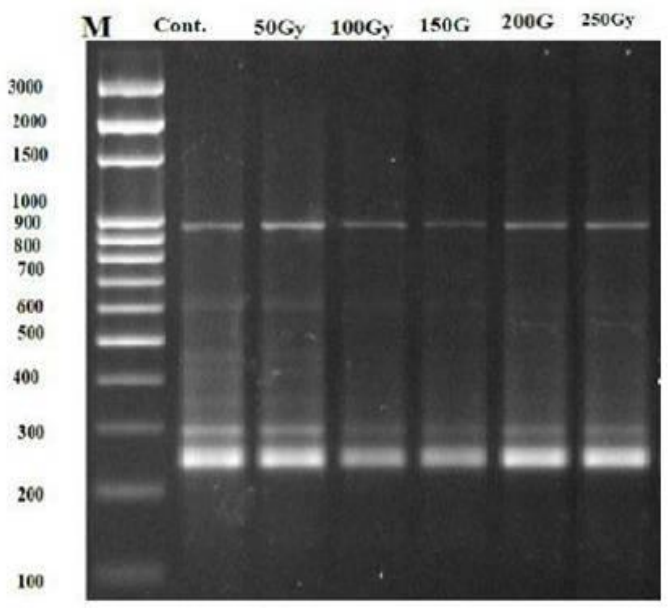

(H)

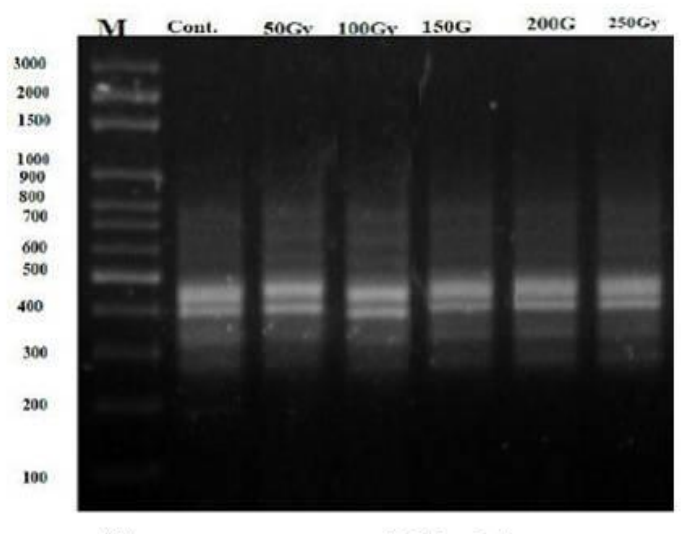

(J)

ISSR- 24

Figure 3 Representative of ten ISSR primers profile of irradiated tomato plantlets. Lane (1) Control (0 Gy); Lane (2) 50 Gy; Lane (3) 100 Gy; Lane (4) 150 Gy; Lane (5) 200 Gy; Lane (6) 250Gy. 
Table 5 Genetic diversity summary between irradiated tomato plantlets with doses $(0,50,100,150,200$ or $250 \mathrm{~Gy})$ revealed by SCoT and ISSR marker analysis

Genetic

parameters

\begin{tabular}{|c|c|c|c|c|c|c|c|c|c|c|c|c|}
\hline parameters & $0 \mathrm{~Gy}$ & $50 \mathrm{~Gy}$ & $100 \mathrm{~Gy}$ & $150 \mathrm{~Gy}$ & $200 \mathrm{~Gy}$ & $250 \mathrm{~Gy}$ & 0 Gy & $50 \mathrm{~Gy}$ & $100 \mathrm{~Gy}$ & $150 \mathrm{~Gy}$ & $200 \mathrm{~Gy}$ & $250 \mathrm{~Gy}$ \\
\hline $\begin{array}{l}\text { Nei's genetic } \\
\text { diversity }(\mathbf{H})\end{array}$ & $\begin{array}{c}0.3592 \\
\pm 0.10\end{array}$ & $\begin{array}{c}0.3323 \\
\pm 0.11\end{array}$ & $\begin{array}{c}0.3758 \\
\pm 0.11\end{array}$ & $\begin{array}{c}0.3046 \\
\pm 0.10\end{array}$ & $\begin{array}{l}0.2499 \\
\pm 0.10\end{array}$ & $\begin{array}{c}0.2569 \\
\pm 0.10\end{array}$ & $\begin{array}{l}0.4295 \\
\pm 0.05\end{array}$ & $\begin{array}{l}0.4136 \\
\pm 0.08\end{array}$ & $\begin{array}{l}0.4205 \\
\pm 0.08\end{array}$ & $\begin{array}{c}0.4166 \\
\pm 0.08\end{array}$ & $\begin{array}{c}0.3849 \\
\pm 0.08\end{array}$ & $\begin{array}{c}0.4217 \\
\pm 0.08\end{array}$ \\
\hline $\begin{array}{l}\text { Shannon's } \\
\text { information } \\
\text { index (I) }\end{array}$ & $\begin{array}{c}0.5391 \\
\pm 0.12\end{array}$ & $\begin{array}{c}0.5075 \\
\pm 0.13\end{array}$ & $\begin{array}{c}0.5574 \\
\pm 0.12\end{array}$ & $\begin{array}{c}0.4766 \\
\pm 0.12\end{array}$ & $\begin{array}{c}0.4097 \\
\pm 0.12\end{array}$ & $\begin{array}{c}0.4171 \\
\pm 0.13\end{array}$ & $\begin{array}{c}0.6198 \\
\pm 0.05\end{array}$ & $\begin{array}{l}0.6013 \\
\pm 0.09\end{array}$ & $\begin{array}{c}0.6082 \\
\pm 0.09\end{array}$ & $\begin{array}{c}0.6043 \\
\pm 0.09\end{array}$ & $\begin{array}{c}0.5704 \\
\pm 0.08\end{array}$ & $\begin{array}{c}0.6096 \\
\pm 0.09\end{array}$ \\
\hline
\end{tabular}

Table 6 Specific markers generated by SCoT and ISSR primers in irradiated tomato plantlets.

\begin{tabular}{|c|c|c|c|}
\hline SCoT & 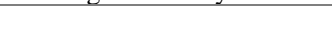 & & ISSR \\
\hline Primer No. & Specific markers & Primer No. & Specific markers \\
\hline SCoT -1 & $219 \mathrm{bp}$ & ISSR- 1 & $878-439-273-231-207 \mathrm{bp}$ \\
\hline SCoT -2 & $277 \mathrm{bp}$ & ISSR- 2 & 0 \\
\hline SCoT -3 & $1026-559-483-476$ bp & ISSR- 4 & 470 \\
\hline SCoT -4 & 0 & ISSR- 5 & 0 \\
\hline SCoT -5 & $259-231 \mathrm{bp}$ & ISSR- 7 & 0 \\
\hline SCoT -12 & 0 & ISSR- 11 & 0 \\
\hline SCoT -13 & 0 & ISSR- 12 & 0 \\
\hline SCoT -16 & 0 & ISSR- 13 & 0 \\
\hline SCoT -20 & 0 & ISSR- 14 & 0 \\
\hline SCoT -33 & $1179-1439-704-547-420 \mathrm{bp}$ & ISSR- 24 & 169 bp \\
\hline
\end{tabular}

\section{Specific markers of irradiated tomato plantlets}

Specific genetic markers were obtained from tomato plantlets irradiated with gamma rays by both SCoT and ISSR primers are summarized in Table 6. Five out of ten SCoT primers tested with irradiated tomato plantlets were successfully to generate specific markers (SCoT- 1, SCoT- 2, SCoT- 3, SCoT- 5 and SCoT33) varying from $219 \mathrm{bp}$ (SCoT- 1) to $1439 \mathrm{bp}$ (SCoT- 33). The SCoT specific markers ranged from one band (SCOT- 1 and SCoT- 2 ) to five bands by SCoT33. On the other hand, of the ISSR primers were screened, seven of the ten primers did not generate specific markers. ISSR- 1, 4 and 24 primers produced specific markers varied from [169 bp (ISSR- 24) to 878 bp (ISSR- 1)]. The highest specific markers were five bands observed with ISSR- 1, while the two other primers generate one band.

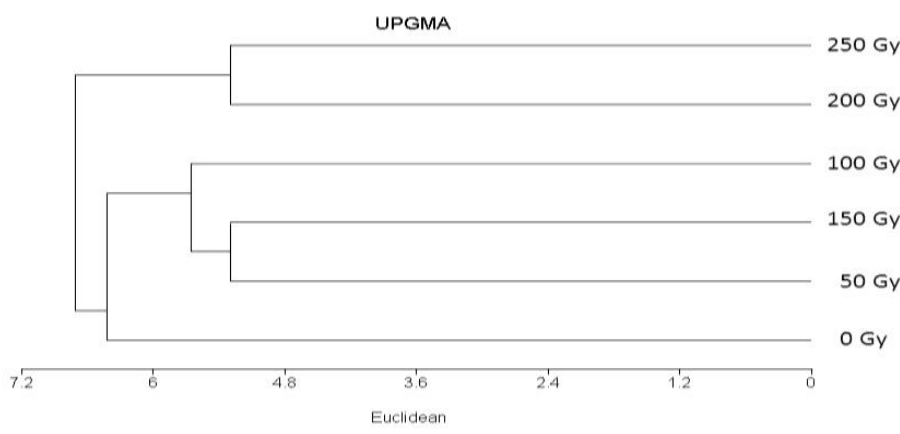

Figure 4 A dendrogram showing the genetic distance among six irradiated tomato plantlets using SCoT data

\section{Genetic relationships}

The genetic relationships between five gamma radiation treatments and nonirradiated tomato plantlets through SCoT and ISSR markers were investigated. Cluster analysis based on Jacquard's similarity coefficients and UPGMA algorithm was calculated. According to both marker ScoT and ISSR dendrogram, the six irradiated tomatoes classified into two groups. Based on SCoT dendrogram, the first group consists of irradiated tomato with doses 50,150 and $100 \mathrm{~Gy}$. However, the second group containing tomato plantlets irradiated with 200 and 250 Gy Fig. 4. On the other side, ISSR dendrogram, the first group consists of tomato plantlets irradiated with doses 50 and $250 \mathrm{~Gy}$, while the second group consists of 100, 150 and 200 Gy Fig. 5 .

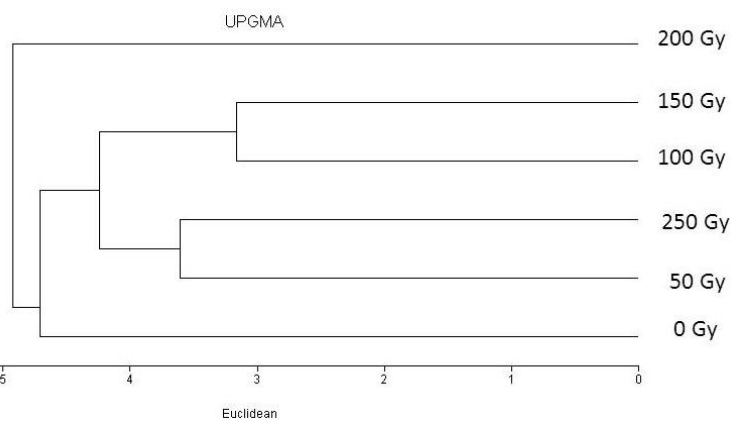

Figure 5 A dendrogram showing the genetic distance among six irradiated tomato plantlets using ISSR data

The efficacy of SCoT and ISSR genetic markers is evaluated via unique criteria such a $P I C$ and $M I$, which were utilized in different research to evaluate exclusive germplasm and cultivated genotypes (Gomes $\boldsymbol{e t}$ al., 2009; Grativol $\boldsymbol{e}$ al., 2011; Patra et al., 2008; Tatikonda et al., 2009). The results received imply that, the each of $P I C$ and $M I$ values will be attributed investigate of genetic diversity. The amplicons number, PIC and $M I$ of the SCoT and ISSR markers observed in this study is comparable to the results acquired through in tomato (Shahlae et al., 2014; Abdein et al., 2018), durum wheat (Etminan et al., 2016), Dendrobium nobile (Bhattacharyya et al., 2013), groundnut (Xiong et al., 2011), mango and (Luo et al., 2010). Nowadays, SCoT marker has been successfully used since its discovery by Collard \& Mackill (2009) in the assessment and analysis of the genetic diversity (Fang-Yong et al., 2014; Jiang et al., 2014; Satya et al., 2015; Zhang et al., 2015), where it proved successful and efficient in the evaluation and analysis of the genetic diversity in order to contain high reproducibility and great power for the detection of polymorphism (Galvan et al., 2003; Cao et al., 2006; Sofalian et al., 2009; Guo et al., 2012; Hamidi et al., 2014). On the other side as well, the ISSR technique is defined as regions in the genome flanked with microsatellite frequencies. These regions through the use of single primers and PCR amplification result from multiple amplification products which can be used to determine genetic variation in most organisms as a dominant multilocus marker. Consequently, this technique is considered to be the easiest and most reliable technique to be compared to other techniques such as RAPD, AFLP, and RLFP (Wang et al. 2012; Shafiei-Astani et al. 2015; Ng \& Tan, 2015). ISSRs have been effectively used to appraise the extent of genetic variation at inter and intraspecific level in a wide range of crop species which include tomato. Primers of ISSR with (AG), (GA), and (CT), (TC), (AC), (CA) repeats show a higher polymorphism than those with other di-, tri- or tetra-nucleotide repeats. AT repeats are the most abundant di-nucleotides in plants. The frequency of Tri and tetra-nucleotides and their use are less dinucleotides. (Shahlaei et al., 2014; Metwali et al., 2016; Etminan et al., 2016; Abdein et al., 2018). In General, the difference between both analyzes (SCoT 
and ISSR) is that each of them with targets on different parts of the genome (Gajeraa et al., 2010).

\section{CONCLUSION}

The use of plant tissue culture techniques has been instrumental in developing, facilitating and overcoming many agricultural problems, including the limitations in the application of mutation techniques. Gamma ray radiation as a physica mutagenic is considered to be the safest and cheapest ways to induce genetic changes in the plant, especially in tissue culture where it is easy to identify and limit these changes accurately and easily. The study proved that both SCoT and ISSR were very successful in detecting genetic changes induced by gamma irradiation. SCoT marker was more accurate and efficient than ISSR marker for identification and genetic diversity analysis of irradiated tomato plantlets.

Acknowledgment: This research was carried out in National Centre for Radiation Research and Technology, Egyptian Atomic Energy Authority.

\section{REFERANCES}

Abdein, M.A., Abdel-Moneim, D., Taha, S.S., Al-Juhani, W.S.M. \& Mohamed S.E. (2018). Molecular characterization and genetic relationships among some tomato genotypes as revealed by ISSR and SCoT markers.Egypt. J. Genet Cytol., 47: 139-159.

Anderson, J.A., Huprikar, S.S., Kochian, L.V., Lucas, W.J. \& Gaber R.F. (1992). Functional expression of a probable Arabidopsis thaliana potassium channel in Saccharomyces cerevisiae. Proc. Natl. Acad. Sci. USA. 89; 37363740. https://doi.org/10.1073/pnas.89.9.3736

Arkita F. N., Azevedo, M. S., Scotton, D. C., Pinto, D. S., Fiqueira, A. \& Peres, L. (2013). Novel natural genetic variation controlling the competence to form adventitious roots and shoots from the tomato wild relative (Solanum pennellii) Plant Sci., 199- 200:121-30. https://doi.org/10.1016/j.plantsci.2012.11.005

Bhatia, P., Ashwath, N. Senaratna, T. \& Midmore, D. (2004). Tissue culture studies of tomato (Lycopersicon esculentum). Plant Cell. Tiss. Organ Cult., 78 1-21. https://doi.org/10.1023/B:TICU.0000020430.08558.6e

Bhattacharyya, P., Kumaria, S., Kumar, S. \& Tandon P. (2013). Start Codon Targeted (SCoT) marker reveals genetic diversity of Dendrobium nobile Lindl. an endangered medicinal orchid species. Gene, 529: 21-26. https://doi: 10.1016/j.gene.2013.07.096

Bookout, D. \& Noble, R. (1987). The effects of IAA on tomato plant regeneration. Plant Physiol., 83:4-76.

Cao, P.J., Yao Q.F., Ding, B.Y., Zeng, H.Y., Zhong, Y.X., Fua, C.X. \& Jin XF (2006). Genetic diversity of Sinojackia dolichocarpa (Styracaceae), a species endangered and endemic to China, detected by inter-simple sequence repeat (ISSR). Biochem Syst Ecol., 34, 231-239. https://doi.org/10.1016/j.bse.2005.11.001

Collard, B.C.Y. \& Mackill, D.J. (2009). Start Codon Targeted (SCOT) polymorphism: A simple novel DNA marker technique for generating genetargeted markers in plants. Plant Molecular Biology, 27: 8693. https://doi.org/10.1007/s11105-008-0060-5

Dewi, I.S., Purwoko, B.S., Aswidinnoor, H., Somantri, I.H. (2004). Kultur antera padi pada beberapa formulasi media yang mengandung poliamin. Journal Bioteknologi Pertanian, 9 (1):14-19.

Dwivedi, K., Srivastava, P., Verma, H.N. \& Chaturvedi, H.C. (1990). Direct regeneration of shoots from leaf segments of tomato (Lycopersicon esculentum) cultured in vitro and production of plants. Indian J. Exp. Biol., 28: 32-3.

El-Bakry, A.A. (2002). Effect of genotype, growth regulators, carbon source and $\mathrm{pH}$ on shoot induction and plant regeneration in tomato. In vitro Cell. Dev. Biol. Plant, 38: 501-507. https://doi.org/10.1079/ivp2002338

El-Fiki, A., Adam, Z., Mohamed, T.H., Sobieh, S.H. \& Salah A. (2018). Molecular Diversity Analysis of Two in vitro and Irradiated Potato Varieties Expressed by Random Amplified Polymorphic DNA. Not Sci Biol., 10 (1):4551. https://doi.org/10.15835/nsb10110157

El-Fiki, A., El-Metabteb, G., Sayed, A. \& Adly, M. (2015). Androgenesis induced in Nicotiana alata and the effect of gamma irradiation. Notulae Scientia Biologicae, 7(1):66-71. https://doi.org/10.15835/nsb719477

El-Fiki, A. \& Adly, M. (2019). Molecular characterization and genetic diversity in some Egyptian wheat (Triticum aestivum L.) using microsatellite markers Potravinarstvo Slovak Journal of Food Sciences. 13(1): 100-108. doi https://doi.org/10.5219/978

El-Fiki, A., Adly, M. \& El-Metabteb, G. (2017). Inter Simple Sequence Repeat DNA (ISSR) Polymorphism utility in haploid Nicotiana Alata irradiated plants for finding markers associated with gamma irradiation and salinity. Arab Journal of Nuclear Science and Applications, 50 (1): 95-102.

El-Fiki, A., Sayed, A., El-Metabteb, G. \& Adly, M. (2016). Genetic Diversity in Haploid Nicotiana alata Induced by Gamma Irradiation, Salt Tolerance and Detection of These Differences by RAPD. Notulae Scientia Biologicae, 8(1):7380. https://doi.org/10.15835/nsb819706

El-Fiki, A., Sayed, A.I.H. \& Abdel-Hameed, A.A.M. (2005a). The combined effect of gamma radiation and mannitol on callus formation and regeneration in alfalfa (Medicago sativa L.). Int J Agric \& Bio., 7(6):966-972. DOI: 10.13140/RG.2.1.3124.2960

El-Fiki, A., Sayed, A.I.H. \& Abdel-Hameed, A.A.M. (2005b). Genotype, explant, medium, light and radiation effects on the in vitro plant regeneration in alfalfa (Medicago sativa L.). Isotope and Radiation Research, 37(2):437-453.

Etminan, M., Myhre, G., Highwood, E.J., \& Shine, K.P. (2016). Applicability of start codon targeted (SCOT) and inter simple sequence repeat. Biotechnology \& Biotechnological Equipment, 30(6): 1075-1081 https://doi.org/10.1080/13102818.2016.1228478

Evans, D A. (1989). Somaclonal variation - Genetic basis and breeding applications, Trends in Genetics, 5:46-50. https://doi.org/10.1016/01689525(89)90021-8

Ezzat A., Adly, M. \& El-Fiki, A. (2019). Morphological, agronomical and molecular characterization in irradiated Cowpea (Vignaunguiculata (L.) Walp.) and detection by start codon target markers, Journal of Radiation Research and
Applied
Sciences,
12
403-412.

https://doi.org/10.1080/16878507.2019.1686578

Fang-Yonga, Ch. \& Ji-Honga, L. (2014). Germplasm genetic diversity of Myrica rubra in Zhejiang Province studied using inter-primer binding site and start codon-targeted polymorphism markers. Scientia Horticulturae, 170: 169-175. https://doi.org/10.1016/j.scienta.2014.03.010

Gajera, B.B. Kumar, N., Singh, A.S., Punvar, B.S., Ravikiran, R., Subhash, N., Jadeja, G.C. (2010). Assessment of genetic diversity in castor (Ricinus communis L.) using RAPD and ISSR markers. Industrial Crops and Products, 32: 491-498. https://doi.org/10.1016/i.indcrop.2010.06.021

Galván, M., Bornet, B., Balatti, P. \& Branchard, M. (2003). Inter simple sequence repeat (ISSR) markers as a tool for the assessment of both genetic diversity and gene pool origin in common bean (Phaseolus vulgaris L.) Euphytica, 132: 297-301. https://doi.org/10.1023/a:1025032622411

Godishala, V., Kairamkonda, M., Kagithoju, S., Mangamoori, L. \& Nanna, R. S. (2012). Zeatin induced direct multiple shoots development and plant regeneration from cotyledon explants of cultivated tomato (Solanum lycopersicum L.). Aust J Crop Sci., 6:31-35.

Gomes, S., Martins-Lopes, P., Lopes, J., et al. (2009). Assessing genetic diversity in Olea europaea L. using ISSR and SSR markers. Plant Mol Biol Rep., 27: 365 373. https://doi.org/10.1007/s11105-009-0106-3

Grativol, C., Lira-Medeiros, C.F., Hemerly, A.S., Ferreira, P.C.G. (2011) High efficiency and reliability of inter-simple sequence repeats (ISSR) markers for evaluation of genetic diversity in Brazilian cultivated Jatropha curcas L. accessions. Mol Biol Rep., 38:4245-4256. https://doi.org/10.1007/s11033-0100547-7

Guo, D., Zhang, J.Y. \&Liu, C.H. (2012). Genetic diversity in some grape varieties revealed by SCoT Analyses. Mol Biol Rep., 39: 5307-5313. https://doi.org/10.1007/s11033-011-1329-6

Gupta, M., Chyi, Y.S., Romero-Severson, J. \& Owen, J.L. (1994). Amplification of DNA markers from evolutionary diverse genomes using single primers of simple-sequence repeats. Theoret. Appl. Genet., 89:9981006. https://doi.org/10.1007/bf00224530

Hamidi, H., Talebi, R. \& Keshavarzi, F. (2014). Comparative efficiency of functional gene-based markers, start codon targeted polymorphism (SCoT) and conserved DNA-derived polymorphism (CDDP) with ISSR markers for diagnostic fingerprinting in wheat (Triticum aestivum L.). Cereal Res Commun. 42(4):558-567. https://doi.org/10.1556/crc.2014.0010

Hasegawa, H., Takashima, S., Nakamura, A. (1995). Effect of gamma ray irradiation on cultured anthers of tobacco (Nicotiana tabacum L.) radiosensitivity and morphological variants appearing in the haploid plants. Plant Tissue Culture Letters, 12(3):281-287. https://doi.org/10.5511/plantbiotechnology1984.12.281

Jain, S.M. (2010). Mutagenesis in crops improvement under the climate change. Romanian Biotechnological Letters, 15: 88-106. https://doi.org/10.25083/rbl Jain, S.M., Brar, D.S. \& Ahloowalia, B.S. (2013). Somaclonal variation and induced mutations in crop improvement. Springer Science \& Business Media., PP.1537. https://doi.org/10.1007/978-94-015-9125-6_2

Jawahar, M., Mohammed, S.V., Jayabalan, N. (1997). A simple protocol for efficient plantlet regeneration from tomato (Lycopersicon esculentum Mill.) hypocotyl derived callus. Plant Tissue culture, 7(1): 35-39.

Jiang, H., Ren, X., Yan, Z., Chen, Y., Zhou, X., Huang, L., Lei, Y., Huang, J., Yan, L., Qi, Y., Wei W. \& Liao, B. (2014). Genetic diversity and population structure of the major peanut (Arachis hypogaea L.) cultivars grown in China by SSR markers. Journal PLoS ONE, 9(2): e88091. https://doi.org/10.1371/journal.pone.0088091

Kalyani, B.G. \& Rao,S. (2014). Zeatin induced direct plant regeneration from cotyledon explants of cultivated tomato (Lycopersicon esculentum Mill.). World J. Pharm. Pharm. Sci., 3: 1034-1040.

Kim, J.H., Baek, M.H., Chung, B.Y., Wi, S.G., Kim, J.S. (2004). Alterations in the photosynthic pigments and antioxidant machineries of red pepper (Capsicum annum L.) seedlings from gamma-irradiated seeds. Journal of Plant Biotechnology, 47(2): 314-321. https://doi.org/10.1007/bf03030546

Kiong, A.L.P., Lai, A.G., Hussein, S., Harun, A. (2008). Physiological responses of Orthosiphon stamineus plantlets to gamma irradiation. American-Eurasian Journal of Sustainable Agriculture, 2(2):135-149. 
Kovach, W.L. (1998). MVSP- A Multivariate Statistical Package for Windows, ver. 3.1. Kovach computing services, Pentraeth, Wales, UK. https://doi.org/10.1553/0x002823e6

Kumar, S., Jindal, S. K., Sarao, N. K. \& Dhaliwal, M. S. (2017). Development of an efficient in vitro regeneration protocol in tomato (Solanum lycopersicum L.). Agric Res J. 54 (4): 475-479. https://doi.org/10.5958/2395-146x.2017.00091.6

Ling, D.X., Luckett, D.J. \& Darvey, N.L. (1991). Low-dose gamma irradiation promotes wheat anther culture response. Aust J Bot., 39: 467 474. https://doi.org/10.1071/bt9910467

Luo, C., He, X.H., Chen, H., Ou, S.J. \& Gao, M.P. (2010). Analysis of diversity and relationships among mango cultivars using Start Codon Targeted (SCoT) markers. Biochem. Syst. Ecol., 38: 11761184. https://doi.org/10.1016/j.bse.2010.11.004

MacDonald, M.V., Hadwieger, M.A., Aslam, F.N. \& Ingram, D.S. (1988). The enhancement of anther culture efficiency in Brassica napus ssp. oleifera Metzg. (Sinsk.) using low doses of gamma irradiation. New Phytol., 110:101-107. https://doi.org/10.1111/j.1469-8137.1988.tb00242.x

Mamidala, P. \& Nanna, R.S. (2011). Effect of genotype, explant source and medium on in vitro regeneration of tomato. Int. J. Genet. Mol. Biol., 3: 45-50.

Metwali, E.M.R., Carle, R., Schweiggert, R.M., Kadasa, N.M., Almaghrabi, O.A (2016). Genetic diversity analysis based on molecular marker and quantitative traits of the response of different tomato (Lycopersicon esculentum Mill.) cultivars to drought stress. Archives of Biological Sciences, 68(2): 427 438. https://doi.org/10.2298/abs150629126m

Meyer, W., Mitchell, T.G., Freedman, E.Z. \& Vilgays, R. (1993). Hybridization probes for conventional DNA fingerprinting used as single primers in the polymerase chain reaction to distinguish strains of Cryptococcus neoformans. $J$ Clin Microbiol., 31: 2274-2280.

Miceska, G. (2011). Determination of the level of androgenesis in tobacco (Nicotiana tabacum L.). Journal of Central European Agriculture, 12(3): 515 518. https://doi.org/10.5513/jcea01/12.3.949

Moghaieb, R.E.A., Saneoka, H. \& Fujita, K. (1999). Plant regeneration from hypocotyl and cotyledon explant of tomato (Lycopersicon esculentum Mill.). Soil Sci. Plant Nutr., 45: 639-546. https://doi.org/10.1080/00380768.1999.10415827 Mohamed, A.A., Ismail, M.R. \& Rahman, M.H. (2010). In vitro response from cotyledon and hypocotyls explants in tomato by inducing 6-benzylaminopurine African J. Biotechnol., 9: 4802-4807.

Murashige, T. \& Skoog, F. (1962). A revised medium for rapid growth and bioassays with tobacco tissue culture. Physiol. Plant., 15, 473-497. https://doi.org/10.1111/j.1399-3054.1962.tb08052.x

Ng, W.L \&Tan, S.G. (2015). Inter-Simple Sequence Repeat (ISSR) Markers: Are We Doing It Right? ASM Sci. J., 9(1): 30-39.

Norfadzrin, F., Ahmed, O.H., Shaharudin, S. \& Abdul Rahman, D. (2007). A preliminary study on gamma radiosensitivity of tomato and okra. International Journal of Agricultural and Research, 2(7): 620 625. https://doi.org/10.3923/ijar.2007.620.625

Patra, B., Acharya, L., \& Mukherjee, A.K.. et al. (2008). Molecular characterization of ten cultivars of Canna lilies (Cannalinn.) using PCR based molecular markers (RAPDs and ISSRs). Int J Integr Biol., 2:129-137.

Pavel, A.B. \& Vasile, C.I. (2012). PyElph - a software tool for gel images analysis and phylogenetics. BMC Bioinformatics, 13:9. doi.org/10.1186/14712105-13-9.

Pino, L. E., Lombardi, C. S., Azevedo, M. S., Scotton, D. C., Borgo, L., Quecini, V., Figueira, A. \& Peres, L. E. P. (2010). The $R g l$ allele as a valuable tool for genetic transformation of the tomato "Micro-Tom" model system. Plant Methods, 6: 23. https://doi.org/10.1186/1746-4811-6-23

Predieri, S. (2001). Mutation induction and tissue culture in improving fruits. Plant Cell Tiss Org. Cult. 64: 185-219. https://doi.org/10.1023/a:1010623203554

Sangwan, R.S. \& Sangwan, B.S. (1986). In: Nuclear techniques and in vitro cultured plant tissues, p. 181-185. IAEA, Vienna.

Sarla, N., Neeraja, C.N. \& Siddiq, E.A. (2000). Determining genetic diversity in Indian landraces of rice using inter-simple sequence repeat (ISSR) polymorphism. Fourth International Rice Genetics Symposium, 22 - 27 October 2000, IRRI, Philippines. Abstracts p. 217.

Satya, P., Karan, M., Jana, S., Mitra, S., Sharma, A., Karmakar, P. \& Ray, D. (2015). Start codon targeted (SCoT) polymorphism reveals genetic diversity in wild and domesticated populations of ramie (Boehmeria nivea L. Gaudich.), a premium textile fiber producing species. Meta Gene, 3: 62 70. https://doi.org/10.1016/j.mgene.2015.01.003

Shafiei-Astani, B., Ong, A.H.K., Valdiani, A., Tan, S.G., Yong, C.S.Y., Ahmady, F., Alitheen, N.B., Ng, W.L. \& Kaur, T. (2015). Molecular genetic variation and structure of Southeast Asian crocodile (Tomistoma schlegelii): comparative potentials of SSRs versus ISSRs. Gene, 571: 107-116 https://doi.org/10.1016/j.gene.2015.06.053

Shahlaei, A., Torabi, S. \& Khosroshahli, M. (2014). Efficiacy of SCoT and ISSR markers in assessment of tomato (Lycopersicum esculentum Mill.) genetic diversity.International Journal of Biosciences. 5(2): 14-22. https://doi.org/10.12692/ijb/5.2.14-22
Sigurbjörnsson, B. (1977). Induction of mutation in wheat, Academy of Sciences, Ukranian SSR, Kiev, USSR,41: 204-217.

Sofalian, O., Chaparzadeh, N. \& Dolati, M. (2009). Genetic diversity in spring wheat landraces from northwest of Iran assessed by ISSR markers. Not Bot Horti Agrobot Cluj-Napoca, 2: 252-256. https://doi.org/10.15835/nbha3723086

Suzuki, N., Koussevitzky, S., Mittler, R. \& Miller, G. (2012). ROS and redox signalling in the response of plants to abiotic stress. Plant Cell Environ, 35:259270. DOI: $10.1111 / \mathrm{j} .1365-3040.2011 .02336 . \mathrm{x}$

Tatikonda, L., Wani, S.P. \& Kannan, S., et al. (2009). AFLP-based molecular characterization of an elite germplasm collection of Jatropha curcas L. a biofuel plant Plant Sci., 176:505- 513. https://doi.org/10.1111/j.1365-3040.2011.02336.x

Terzopoulos, P.J. \& Bebeli, P.J. (2008). DNA and morphological diversity of selected Greek tomato (Solanum lycopersicum L.) landraces. Scientia Horticulturae, 116: 354- 361. https://doi.org/10.1016/j.scienta.2008.02.010

Varshney, R.K., Marcel, T.C., Ramsay, L., Russell, J., Röder, M.S., Stein, N., Waugh, R., Langridge, P., Niks, R.E., \& Graner, A. (2007). A high density barley microsatellite consensus map with 775 SSR loci. Theor Appl Genet., 114(6): 1091-1103. https://doi.org/10.1007/s00122-007-0503-7

Wang, X., Yang, R., Feng, S., Hou, X., Zhang, Y., Li, Y., \& Ren, Y. (2012) 'Genetic variation in Rheum palmatum and Rheum tanguticum (Polygonaceae), two medicinally and endemic species in China using ISSR markers', PLOS One 7: e51667. https://doi.org/10.1371/journal.pone.0051667

Wi, S.G., Chung, B.Y., Kim, J.H., Baek, M.H., Yang, D.H., Lee, J.W., \& Kim, J.S. (2005). Ultrastructural changes of cell organelles in Arabidopsis stem after gamma irradiation. J. Plant Biol., $48 \quad$ (2): 195 200. https://doi.org/10.1007/bf03030408

Wu, K., Jones, R., Dannaeberger, L., \& Scolnik, P.A. (1994). Detection of microsatellite polymorphisms without cloning. Nucleic Acids Res., 22: $3257-$ 3258. https://doi.org/10.1093/nar/22.15.3257

Xiong, F., Zhong, R., Han, Z., Jing, J., He, L., Zhuang, W., \& Tang, R. (2011) Start codon targeted polymorphism for evaluation of functional genetic variation and relationships in cultivated peanut (Arachis hypogaea L.) genotypes. Mol. Biol. Rep., 38: 3487-3494. https://doi.org/10.1007/s11033-010-0459-6

Yeh, F.C., Yang, R.C., Boyle, T.B.J., Ye, Z.H., \& Mao, J.X. (1999). POPGENE The user friendly software for population genetic analysis.

Zhang, J., Xie, W., Wang, Y., \& Zhao, X. (2015). Potential of start codon targeted (SCOT) markers to estimate genetic diversity and relationships among Chinese Elymus sibiricus accessions. Molecule. 20: 5987- 6001. https://doi.org/10.3390/molecules20045987

Zietkiewicz, E., Rafalski, A., \& Labuda, D. (1994). Genome fingerprinting by simple sequence repeat (SSR) anchored polymerase chain reaction amplification. Genomics, 20: 176-183. https://doi.org/10.1006/geno.1994.1151 